\title{
Dampak Kebijakkan Pembatasan Sosial Berskala Besar (PSBB) Dan Media Komunikasi Daring Saat Pendemi Covid-19 Terhadap Aktivitas Otot Ekstremitas Atas
}

\author{
Sri Yani ${ }^{1)}$, Agustiyawan ${ }^{1)}$, Dias Rima Sutiono ${ }^{2)}$ \\ ${ }^{1)}$ Fisioterapi , Fakultas Ilmu Kesehatan, UPN Veteran Jakarta \\ ${ }^{1)}$ Alumni Teknologi Biomedis, Pascasarjana, Universitas Indonesia \\ Email: sri.yani@upnvj.ac.id
}

\begin{abstract}
The government enforced the PSBB (Large-Scale Social Restriction) policy as an effort to overcome the COVID-19 pandemic due to the spread of the Sars-Cov-2 virus which originated from Wuhan, China in December 2019 in accordance with WHO regulations. This is because until now a vaccine has not been found to prevent transmission. As a result of this policy, darling communication media is very important to socialize with relatives and friends, causing a decrease in physical activity. Based on data from the darling survey conducted on 40 students of the Department of Physiotherapy, Faculty of Health Sciences, UPN Veteran Jakarta, $40 \%$ of respondents stated that communication time had increased from before the pandemic period, $35 \%$ of respondents said it had not changed and the remaining $25 \%$ said it was less. While the duration of communication most of the respondents spent socializing with darling communication media using the ZOOM and Video Call applications was for 1-30 minutes as many as $52.5 \%$ of respondents, $31-1$ hours by $27.5 \%$ of respondents, more than 1 hour as many as $17.5 \%$ and 0 minutes as much as $2.5 \%$ of respondents. This condition causes the repetitive upper limb movements required by the use of darling communication media devices resulting in continuous muscle contraction in the neck and shoulders, which can lead to susceptibility to musculoskeletal disorders due to microscopic damage to muscles, nerves and blood vessels during their role.
\end{abstract}

Keywords: PSBB, Communication, Covid-19, Upper limb activity

\begin{abstract}
ABSTRAK
Pemerintah memberlakukan kebijakkan PSBB (Pembatasan Sosial Berskala Besar) sebagai salah satu upaya mengatasi pandemi COVID-19 akibat penyebaran virus Sars-Cov-2 yang berasal dari Wuhan, China Desember tahun 2019 sesuai dengan peraturan WHO. Hal ini dikarenakan hingga saat ini belum ditemukan vaksin untuk mencegah penularannya. Akibat dari kebijakkan tersebut, media komunikasi darling menjadi sangat penting untuk bersosialisasi dengan kerabat maupun teman, menyebabkan penurunan aktifitas fisik. Berdasarkan data darling survei yang dilakukan pada 40 orang mahasiswa Jurusan Fisioterapi, Fakultas Ilmu Kesehatan, UPN Veteran Jakarta, 40 \% responden menyatakan waktu berkomunikasi bertambah dari sebelum masa pandemi, $35 \%$ responden menyatakan tidak berubah dan sisanya 25\% menyatakan kurang. Sedangkan durasi komunikasi yang paling banyak dihabiskan oleh responden untuk bersosialisasi dengan media komunikasi darling dengan menggunakan aplikasi ZOOM dan Video Call adalah selama 1-30 menit sebanyak 52.5\% responden, 31-1 jam sebanyak 27.5\% responden, lebih dari 1 jam sebanyak $17.5 \%$ dan 0 menit sebanyak $2.5 \%$ responden. Kondisi ini menyebabkan gerakan ekstremitas atas berulang yang diperlukan oleh penggunaan perangkat media komunikasi darling sehingga kontraksi otot secara terus menerus di leher dan bahu, yang dapat menimbulkan kerentanan terhadap gangguan muskuloskeletal akibat kerusakan mikroskopis pada otot, saraf, dan pembuluh darah selama menjalankan perannya.
\end{abstract}

Keywords : PSBB, Komunikasi, Covid-19, Aktivitas ekstremitas atas 


\section{PENDAHULUAN}

WHO menyatakan bahwa COVID-19 disebabkan oleh Virus Sars-Cov-2 sebagai pandemi sehingga untuk menurunkan tingkat penularannya baik kelompok sehat maupun kelompok dengan penyakit penyerta diharuskan menerapkan jaga jarak dan kebijakkan isolasi yang diadopsi diseluruh dunia.

Hal ini disebabkan oleh belum tersedianya pencegahan secara khusus dan intervensi medis terapeutik untuk infeksi tersebut, disamping tingkat penularan yang cepat membuat individu secara ilmiah direkomendasikan untuk tinggal di rumah dan menghindari interaksi sosial yang dapat berpotensi meningkatkan ketidakaktifan fisik ${ }^{(1)}$. Jika bentuk kebijakkan isolasi sosial yang diberlakukan diseluruh dunia adalah "Lock down" maka di Indonesia diterapkan Pembatasan sosial berskala besar (PSBB). Sesuai dengan surat keputusan Menteri Kesehatan RI Nomor HK.01.07/MENKES/239/2020 dalam rangka Percepatan Penanganan Covid-19, pemberlakuan kebijakkan PSBB yang pertama di Indonesia adalah Provinsi DKI Jakarta.

Kebijakkan PSBB selama pandemi COVID 19 telah merubah kebiasaan individu berinteraksi dengan individu lainnya, karena diizinkan keluar rumah jika hanya memiliki kebutuhan yang mendesak ${ }^{(2)}$. Perubahan ini terjadi secara tibatiba, yang pada awalnya hanya beberapa pemerintahan menyatakan bahwa tindakan tersebut tidak perlu dan kemudian tiba-tiba menuntut semua orang untuk tetap tinggal di rumah ${ }^{(3)}$. Perubahan tersebut juga memiliki durasi yang tidak pasti; PSBB diberlakukan selama beberapa minggu, tetapi diperpanjang menjadi beberapa bulan, dan aturan untuk jaga jarak terus diterapkan ${ }^{(4)}$.

Sehingga masyarakat banyak yang menghabiskan waktu dengan menggunakan media komunikasi daring. Platform media sosial telah mengalami peningkatan penggunaan sebesar $61 \%$ karena banyak orang ingin tetap terhubung dengan keluarga, teman, dan kolega (5). Facebook dan Instagram mengalami peningkatan lebih dari $40 \%$ di seluruh dunia dari Februari hingga Maret 2020; olah pesan di Facebook Messenger, WhatsApp, dan Instagram meningkat $70 \%$ selama periode ini, dan penayangan streaming langsung meningkat dua kali lipat ${ }^{(6)}$.

Berolo dkk. melaporkan bahwa pengguna perangkat genggam seluler mengeluhkan ketidaknyamanan di setidaknya satu area ekstremitas atas, punggung atas, atau leher. Para peneliti juga melaporkan hubungan yang signifikan antara total waktu yang dihabiskan menggunakan perangkat seluler setiap hari dan rasa sakit di bahu kanan, dan antara waktu yang dihabiskan untuk menjelajah internet dan nyeri di pangkal ibu jari kanan ${ }^{(7)}$. Suatu pertanyaan muncul mengenai dampak kebijakkan Pembatasan Sosial Berskala besar (PSBB) dan media komunikasi daring saat pandemi COViD 19 terhadap area ekstremitas atas, jika 
kebijakkan ini terus menerus diberlakukan. Oleh karena itu, penelitian ini bertujuan untuk mengetahui dan menganalisa dampak yang disebutkan diatas pada mahasiswa yang diharuskan belajar dari rumah.

\section{METODE}

\subsection{Responden}

Partisipasi bersifat sukarela dan responden diminta untuk mengisi kuesioner secara darling yang didistribusikan ke ponsel individu yang terhubung ke jejaring sosial penulis. Persetujuan untuk penelitian ini diperoleh dari dewan peninjau kelembagaan yang relevan dari penulis dan responden diminta untuk membaca deskripsi penelitian dan memberikan persetujuan secara darling sebelum menyelesaikan survei. Responden merupakan mahasiswa jurusan Fisioterapi, fakultas ilmu kesehatan, UPN Veteran Jakarta sebanyak 40 orang.

\subsection{Material dan Desain}

Pada penelitian ini diberikan dengan beberapa pertanyaan survei yang dirancang untuk melihat peningkatan penggunaan media komunikasi daring saat pandemi COViD 19 saat diberlakukannya kebijakkan Pembatasan Sosial Berskala besar (PSBB) dan dampaknya pada aktivitas fisik. Variabel ini mengukur durasi komunikasi dengan media darling mengalami perubahan atau tidak selama kebijakkan PSBB.

\section{PEMBAHASAN}

Dalam konteks pandemi, setiap individu merubah perilakunya dalam bersosialisasi dan hidup bermasyarakat untuk melindungi diri sendiri dari infeksi, dengan menerapkan jaga jarak dan peningkatan kebersihan pribadi ${ }^{(8)}$. Jaga jarak mengarah pada penyesuaian diri terhadap kebijakkan untuk menghindari penularan (9), seperti mengurangi frekuensi kontak dengan orang lain ${ }^{(10)}$, menjaga jarak yang cukup saat berkomunikasi tatap muka ${ }^{(11)}$, tinggal di rumah untuk waktu yang lama, dan menghindari keramaian ${ }^{(12)}$.

Penggunaan media sosial mengalami peningkatan yang sangat pesat akibat kebijakkan "Lock down" dan "social distancing" di seluruh dunia. Sebagai kompensasinya, akhirnya semua orang beralih ke media social dengan menggunakan teknologi elektronik untuk dapat berkomunikasi ataupun terhubung dengan orang lain ${ }^{(13)}$.

Berdasarkan hasil survey secara daring yang dilakukan pada 40 orang mahasiswa jurusan Fisioterapi, fakultas ilmu kesehatan, UPN Veteran Jakarta bahwa $40 \%$ responden menyatakan waktu berkomunikasi bertambah dari sebelum masa pandemi, $35 \%$ responden menyatakan tidak berubah dan sisanya $25 \%$ menyatakan kurang. Sedangkan durasi komunikasi yang paling banyak dihabiskan oleh responden untuk bersosialisasi dengan media komunikasi darling dengan menggunakan aplikasi ZOOM dan Video Call adalah selama 130 menit sebanyak $52.5 \%$ responden, 31-1 jam sebanyak $27.5 \%$ responden, lebih dari 1 jam 
sebanyak $17.5 \%$ dan 0 menit sebanyak $2.5 \%$ responden.

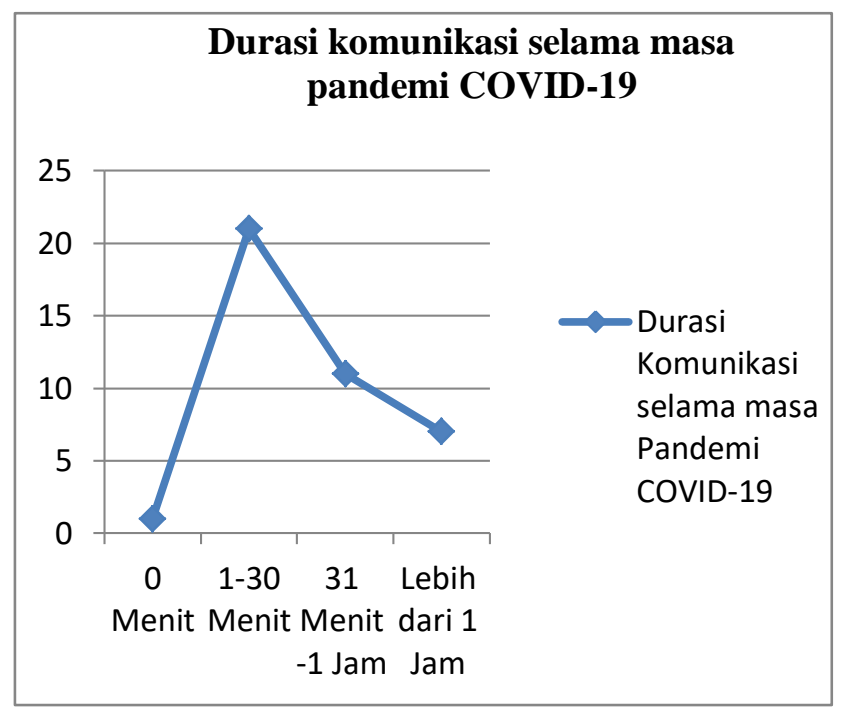

Gambar 1. Grafik Durasi Komunikasi selama masa Pandemi COVID-19

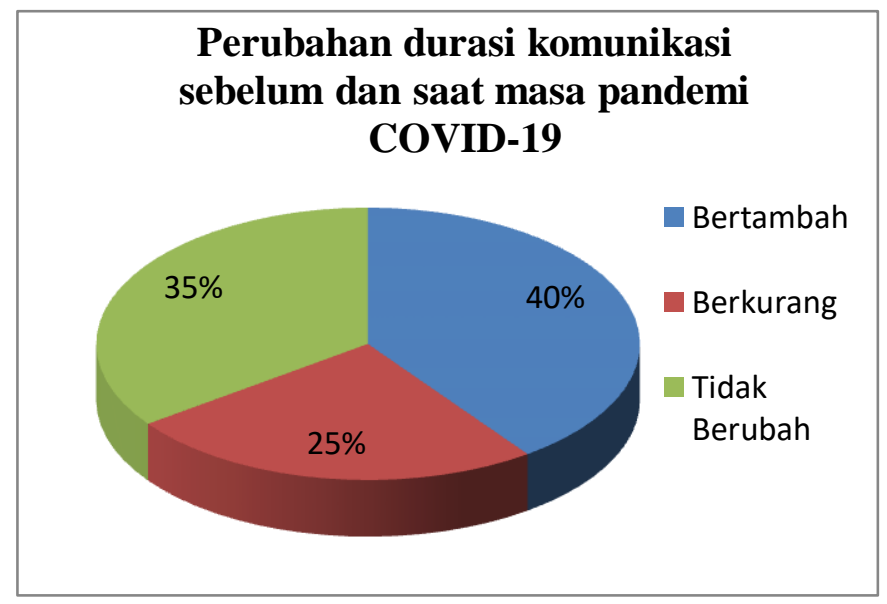

Gambar 2. Diagram Pie Perubahan durasi komunikasi sebelum dan saat masa pandemi COVID-19
Dengan demikian, banyaknya responden yang menambah durasi penggunaan media komunikasi darling Zoom dan Video Call untuk berkomunikasi dengan keluarga ataupun teman saat kebijakkan Pembatasan Sosial Berskala besar (PSBB) diberlakukan dengan sebelum masa pandemi COVID-19 berdapak pada berkurangnya aktivitas otot ekstremitas atas.

Gerakan ekstremitas atas yang terus berulang dan konsisten dalam penggunaan perangkat media komunikasi darling menyebabkan kontraksi otot terus menerus di leher dan bahu, yang dapat menyebabkan kerentanan terhadap gangguan muskuloskeletal karena kerusakan mikroskopis pada otot, saraf, dan pembuluh darah selama pelaksanaan perannya ${ }^{(14)}$. Posisi statis dan asimetris yang digunakan selama penggunaan perangkat tersebut juga dapat menjadi faktor risiko potensial gangguan musculoskeletal ${ }^{(15)}$.

Hal ini dapat menyebabkan peningkatan risiko kardiovaskuler yang dipicu oleh ketidakaktifan fisik dapat diperburuk oleh perubahan lain seperti pengecilan otot, peningkatan lemak viseral, hiperglikemia, dan dislipidemia ${ }^{(16)}$.

\section{KESIMPULAN}

Pandemi COVID-19 menyebabkan perubahan kebiasaan masyarakat dalam bersosialisasi. Hasil survei online yang dilakukan pada 40 orang mahasiswa bahwa $40 \%$ responden menyatakan waktu berkomunikasi bertambah dari sebelum masa pandemi, $35 \%$ responden menyatakan 
tidak berubah dan sisanya $25 \%$ menyatakan kurang. Hal ini berdampak pada ketidakaktifan fisik dikarenakan aktifitas fisik dilakukan hanya duduk.

\section{REFERENSI}

[1] Peçanha,Tiago, Karla Fabiana Goessler, Hamilton Roschel, dan Bruno Gualano. 2020. Integrative Cardiovascular Physiology and Pathophysiology Social isolation during the COVID-19 pandemic can increase physical inactivity and the global burden of cardiovascular disease. Am J Physiol Heart Circ Physiol 318: H1441H1446. doi:10.1152/ajpheart.00268.2020.

[2] Williams, Z. 2020. Don't stand so close to me! England's new rules of social distancing. The Guardian June 2. https://www.theguardian.com/lifeandstyle/2 020/jun/02/dontstand-so-close-to-me-thenew-rules-of-social-distancing, (Accessed 14 June 2020).

[3] Kent, J. 2020. COVID-19 data shows how social distancing impacts virus spread. Health IT Analytics June 2. https://healthitanalytics.com/news/covid-19data-shows-howsocial-distancing-impactsvirus-spread, (Accessed 14 June 2020).

[4] Kamin, D. 2020. Relaxing the rules of social distancing. The New York Times June 2. https://www.nytimes.com/2020/06/02/reales tate/virus-social-distancingetiquetterules.htm (Accessed 14 June 2020).
[5] Holmes, R. 2020. Is COVID-19 social media's levelling up moment? Forbes April 24.https://www.forbes.com/sites/ryanholme s/2020/04/24/is-covid-19-socialmediaslevelling-upmoment/\#32e022256c60 (Accessed 5 June 2020).

[6] Perez, S. 2020c. Report: WhatsApp has seen a $40 \%$ increase in usage due to COVID-19 pandemic TechCrunchTechCrunch March 26.

https://techcrunch.com/2020/03/26/reportwhatsapp-has-seen-a-40-increase-in-usagedue-to-covid-19-pandemicl, (Accessed 5 June 2020).

[7] Berolo S, Wells RP, Amick BC, 3rd: Musculoskeletal symptoms among mobile hand-held device users and their relationship to device use: a preliminary study in a Canadian university population. Appl Ergon, 2011, 42: 371-378.

[8] Cowling, B. J., Ng, D. M., Ip, D. K., Liao, Q., Lam, W. W., Wu, J. T., Lau, J. T. F., Griffiths, S. M., \& Fielding, R. 2010. Community psychological and behavioral responses through the first wave of the 2009 influenza A (H1N1) pandemic in Hong Kong. Journal of Infectious Diseases, 202(6), 867-876. https://doi.org/10.1086/655811.

[9] Caley, P., Philp, D. J., \& McCracken, K. W. J. 2008. Quantifying social distancing arising from pandemic influenza. Journal of 
the Royal Society Interface, 5(23), 631639. https://doi.org/10.1098/rsif.2007.1197

[10] Reluga, T. C. 2010. Game theory of social distancing in response to an epidemic. PLoS Computational Biology, 6(5), e1000793. https://doi.org/10.1371/journal.pcbi.100079 3.

[11] Morrison, L. G., \& Yardley, L. 2009. What infection control measures will people carry out to reduce transmission of pandemic influenza? A focus group study. BMC Public Health, 9(1), 258. https://doi.org/10.1186/1471-2458-9-258.

[12] Glass, R. J., Glass, L. M., Beyeler, W. E., \& Min, H. J. 2006. Targeted social distancing designs for pandemic influenza. Emerging Infectious Diseases, 12(11), 1671-1681. https://doi.org/10.3201/eid1211.060255

[13] Fox, L. 2020. COVID fears spawn social media shaming. The Alpena News April 22.https://www.thealpenanews.com/news/lo cal-news/2020/04/covid-fears-spawnsocialmedia-shaming/, (Accessed 5 June 2020).

[14] Kim GY, Ahn CS, Jeon HW, et al. : Effects of the use of smartphones on pain and muscle fatigue in the upper extremity. $\mathrm{J}$ Phys Ther Sci, 2012, 24: 1255-1258.
[15] Ko K, Kim HS, Woo JH: The study of muscle fatigue and risks of musculoskeletal system disorders from text inputting on smartphone. J Ergo Soc Korea, 2013, 32: 273-278.

[16] Bienso RS, Ringholm S, Kiilerich K, Aachmann-Andersen NJ, Krogh-Madsen R, Guerra B, Plomgaard P, van Hall G, Treebak JT, Saltin B,Lundby C, Calbet JA, Pilegaard H, Wojtaszewski JFP. 2012. GLUT4 andglycogen synthase are key players in bed rest-induced insulin resistance.Diabetes61:

1090-1099. doi:10.2337/db11-0884

Penulis menyatakan tidak ada konflik interest dalam penulisan jurnal ini.

Dana Penelitian : UPN Veteran Jakarta State

No Ethical Approval : 2792/X/2020/KEPK 